\title{
Latanoprostene Bunod, a Dual-acting Nitric Oxide Donating Prostaglandin Analog for Lowering of Intraocular Pressure
}

\author{
Robert N Weinreb, ${ }^{1}$ Tony Realini, ${ }^{2}$ and Rohit Varma ${ }^{3}$ \\ 1. Chairman and Distinguished Professor of Ophthalmology, Shiley Eye Institute and Hamilton Glaucoma Center and Department of Ophthalmology, \\ UC San Diego, California, US; 2. Professor of Ophthalmology, West Virginia University, West Virginia, US; 3. Grace and Emery Beardsley Professor and \\ Chair, USC Department of Ophthalmology; Director, USC Roski Eye Institute, Associate Dean for Strategic Planning and Network Development, Keck \\ school of Medicine University of Southern California, California, US
}

DOI: https://doi.org/10.17925/USOR.2016.09.02.80

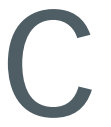
urrent topical treatments for glaucoma have limited efficacy in lowering intraocular pressure (IOP) and/or can produce side effects and tolerability problems. At present, IOP remains the only known modifiable risk factor to delay the progression of glaucoma. The novel IOP-lowering treatment latanoprostene bunod (LBN) is a nitric oxide (NO)-donating prostaglandin $\mathrm{F}_{2 \alpha}$ analog that is rapidly metabolized in situ to latanoprost acid and butanediol mononitrate, an NO-donating moiety. LBN has a dual action in that it enhances aqueous humor outflow via both the uveoscleral and trabecular meshwork pathways. It is undergoing regulatory review by the Food and Drug Administration (FDA) for the reduction of IOP in patients with open-angle glaucoma (OAG) or ocular hypertension (OHT). In the dose-ranging VOYAGER study, LBN 0.024\%, the lower of the most effective concentrations evaluated, demonstrated significantly greater IOP lowering and comparable side effects compared with latanoprost $0.005 \%$. The recent APOLLO phase III clinical study $(n=420)$ found LBN $0.024 \%$ demonstrated significantly greater reductions in IOP than timolol $0.5 \%$ in patients with OAG or OHT at various time points over 3 months. The same study found the proportion of patients with IOP $\leq 18 \mathrm{mmHg}$ was significantly greater with LBN $0.024 \%$ than with timolol $0.5 \%$. In the LUNAR study $(n=420)$, LBN $0.024 \%$ was non-inferior to timolol $0.5 \%$ over 3 months' treatment. LBN treatment also resulted in significantly greater IOP lowering than timolol at all time-points with the exception of the first post-baseline assessment. In JUPITER, a study of 130 subjects with OAG or OHT, LBN 0.024\% was safe and well tolerated when used for up to a year, and provided significant and sustained IOP reduction. Further, in CONSTELLATION, a study of 25 patients with OHT or OAG, IOP lowering with LBN $0.024 \%$ was consistently lower than baseline during both the diurnal/wake and nocturnal/sleep periods whereas timolol $0.5 \%$ reduced IOP only during the diurnal period. In addition, LBN $0.024 \%$ treatment resulted in a significantly increased diurnal ocular perfusion pressure versus baseline and nocturnal ocular perfusion pressure versus timolol $0.05 \%$. Similarly, in KRONUS, a single-arm, single-center, openlabel study of 24 healthy Japanese subjects, LBN 0.024\% significantly lowered mean IOP over a 24-hour period. Across these studies, LBN has demonstrated a favorable safely profile and good ocular tolerability. It is hypothesized that LBN's dual action on the outflow pathways accounts for the improved efficacy when compared with latanoprost and timolol.

\section{Keywords}

Glaucoma, intraocular pressure, nitric oxide, latanoprostene bunod

Disclosure: Robert N Weinreb has been a consultant to Aerie Pharmaceuticals, Alcon, Allergan, Bausch \& Lomb, and ForSightV. He has received research grants from Genentech and Quark and research instruments from Heidelberg Engineering, Optovue, Topcon, and Zeiss. Tony Realini has been a consultat to Alcon, Bausch \& Lomb/Valeant, Envisia, Inotek, and Smith and Nephew, and received research support from Alcon, Roche and Aerie. Rohit Varma has been a consultant to Aerie Pharmaceuticals, Allergan, Bausch \& Lomb, Genentech, and Isarna. This study involves a review of the literature and did not involve any studies with human or animal subjects performed by any of the authors.

Acknowledgments: Medical writing assistance was provided by Catherine Amey and James Gilbart at Touch Medical Media, UK with assistance from Michelle Dalton, Dalton \& Associates, US.

Open Access: This article is published under the Creative Commons Attribution Noncommercial License, which permits any noncommercial use, distribution, adaptation, and reproduction provided the original author(s) and source are given appropriate credit.

Received: August 22, 2016 Accepted: September 14, 2016

Citation: US Ophthalmic Review, 2016;9(2):80-7

Corresponding Author: Robert N Weinreb, Shiley Eye Institute, 415 Campus Point Dr, La Jolla, California 92037, US. E: hiiop@aol.com

Support: The publication of this article was supported by Bausch \& Lomb, who were given the opportunity to review the article for scientific accuracy before submission. Any resulting changes were made at the author's discretion.
Glaucoma is a multifaceted disorder resulting from damage to the retinal ganglion cells (RGCS) and their axons, causing progressive optic nerve degeneration and leading to irreversible blindness in some patients. ${ }^{1-4}$ In most cases the condition develops gradually, with peripheral vision loss typically being followed by loss of central vision. ${ }^{5}$ In the US, in 2011, openangle glaucoma (OAG) affected 2.71 million persons and is estimated to rise to 7.32 million by $2050 .{ }^{6}$ Globally, glaucoma affected an estimated 64.3 million people (aged 40-80 years) in 2013.7 Given the aging of the world's population, this number is expected to rise to 76.0 million in 2020 and to 111.8 million in 2040 .?

Ocular hypertension (OHT) can be defined as a high intraocular pressure (IOP) without observable optic nerve damage. ${ }^{4}$ OAG and angleclosure glaucoma are the two predominant types of glaucoma, and are characterized by an elevated IOP. ${ }^{9}$ Normal tension glaucoma (NTG) is a form of OAG that is prevalent in both Japanese and Western populations. ${ }^{10}$ While damage to the optic nerve occurs without elevation of IOP in NTG, IOP reduction has been shown to reduce visual field damage in patients with NTG. ${ }^{10}$ 


\begin{tabular}{|c|c|c|c|c|}
\hline & Top-line properties & Drug & Average IOP reduction & Safety \\
\hline $\begin{array}{l}\text { Prostaglandin analogs } \\
\text { (first-line drug) }\end{array}$ & $\begin{array}{l}\text { Increase uveoscleral outflow. } \\
\text { Once-daily dosing except for } \\
\text { unoprostone, which requires twice- } \\
\text { daily administration }\end{array}$ & $\begin{array}{l}\text { Latanoprost } \\
\text { Travoprost } \\
\text { Tafluprost } \\
\text { Unoprostone } \\
\text { Bimatoprost }\end{array}$ & $\begin{array}{l}\text { 18-31\% during day time } \\
\text { and about } 8.5-17 \% \\
\text { during night time }\end{array}$ & $\begin{array}{l}\text { Mild conjunctival hyperemia, darkening of the irises, } \\
\text { hypertrichosis, hyperpigmentation of the eye lashes } \\
\text { and iris, periorbital fat atrophy, local irritation, cystoid } \\
\text { macular edema, increased eyelash growth }\end{array}$ \\
\hline $\begin{array}{l}\beta \text {-adrenergic receptor } \\
\text { antagonists* (first-line } \\
\text { drug) }\end{array}$ & $\begin{array}{l}\text { Reduce the production and secretion } \\
\text { of aqueous humor, thereby reduce IOP. } \\
\text { Twice-daily dosing }\end{array}$ & $\begin{array}{l}\text { Timolol } \\
\text { Levobunolol } \\
\text { Carteolol } \\
\text { Metipranolol } \\
\text { Betaxolol }\end{array}$ & $20-27 \%$ during day time & $\begin{array}{l}\text { Stinging, blurring, local irritation, bronchospasm, } \\
\text { headache, bradycardia, hypotension, dizziness, } \\
\text { ocular pain, superficial punctuate keratitis, dryness, } \\
\text { conjunctival hyperemia }\end{array}$ \\
\hline $\begin{array}{l}\alpha 2 \text {-adrenergic receptor } \\
\text { agonists (second-line } \\
\text { treatments) }\end{array}$ & $\begin{array}{l}\text { Decrease aqueous humor production; } \\
\text { increased uveoscleral outflow. } \\
\text { Thrice-daily dosing }\end{array}$ & $\begin{array}{l}\text { Brimonidine tartrate } \\
\text { Dipivefrin hydrochloride } \\
\text { Apraclonidine } \\
\text { Hydrochloride } \\
\text { Epinephrine** }\end{array}$ & $12.5-29 \%$ & $\begin{array}{l}\text { Blepharoconjunctivitis, conjunctival hyperemia, blurry } \\
\text { vision, irritation, dry mouth, drowsiness, ocular allergy, } \\
\text { systemic hypotension, fatigue, headache, palpitations, } \\
\text { high blood pressure, anxiety }\end{array}$ \\
\hline $\begin{array}{l}\text { Cholinergic drugs } \\
\text { (second-line } \\
\text { treatments) }\end{array}$ & $\begin{array}{l}\text { Increase trabecular aqueous humor } \\
\text { outflow by contraction of ciliary } \\
\text { muscle and scleral spur. Thrice-daily } \\
\text { dosing except once daily dosing for } \\
\text { echothiophate }\end{array}$ & $\begin{array}{l}\text { Pilocarpine } \\
\text { Carbachol } \\
\text { Echothiophate }\end{array}$ & + & $\begin{array}{l}\text { Pupillary constriction, ocular burning, brow ache, } \\
\text { reduced night vision }\end{array}$ \\
\hline
\end{tabular}

$1 O P=$ intraocular pressure. *Two types of topical beta-blockers are available for use in glaucoma: nonselective, which block both beta 1- and beta 2-adrenoceptors, and cardioselective, which block predominantly beta 1-receptors. **In the eye, epinephrine functions as a non-selective $\beta 2$-adrenergic agonist in addition to other functions; +IOP reduction data not available.

Current treatment options target IOP reduction to delay progressive glaucomatous damage and to delay onset of visual field loss in subjects with $\mathrm{OHT}$; these include topical medications, laser trabeculoplasty, and surgical drainage procedures (micro-invasive glaucoma surgery [MIGS], trabeculectomy, tube shunts). ${ }^{11-13}$ However, commonly used topical treatments (prostaglandin analogs [PGA], beta blockers, carbonic anhydrase inhibitors, and $\alpha$-adrenergic agonists) can be limited by ocular and systemic side effects, allergies, the need for multiple administrations every day, poor adherence/compliance, and an inability to consistently control 24-hour IOP (Table 1). A new molecular entity incorporating both the established prostaglandin $\mathrm{F}_{2 \alpha}\left(\mathrm{PGF}_{2 \alpha}\right)$ analog, latanoprost acid and a nitric oxide (NO)-donating group (latanoprostene bunod [LBN, BOL-303259-X] Bausch \& Lomb Inc. Bridgewater, NJ, USA) is currently under review by the Food and Drug Administration (FDA) in the US as a novel IOP-lowering monotherapy for glaucoma management. This review discusses the dual mechanism of action of this potential new treatment and evaluates the clinical evidence supporting the compound's efficacy.

\section{Pathophysiology of glaucoma}

Increased IOP raises risk for glaucoma, which is characterized by RGC damage and death that results in changes to the optic nerve head and the visual field. IOP is affected by the balance between aqueous humor (AH) secretion and its subsequent drainage through the trabecular meshwork (TM) and the uveoscleral outflow pathway., ${ }^{5,14-17} \mathrm{AH}$ is secreted into the anterior chamber via the ciliary epithelium and returns to the vasculature through the TM into Schlemm's canal, draining into collector channels, aqueous and episcleral veins; or it is drained via the uveoscleral route. Recent laboratory studies show cyclic IOP changes, possibly prompted by a reduction in pressure-dependent drainage, alter this aqueous outflow. ${ }^{18}$ At least $75 \%$ of the resistance to $\mathrm{AH}$ outflow in humans is localized within the TM, predominantly in the juxtacanalicular portion; in glaucoma, this tissue is altered leading to elevated IOP. ${ }^{16}$ In addition to IOP, other risk factors affecting the development and/or progression of glaucoma include older age, African ancestry or Hispanic ethnicity, larger optic nerve cup-to-disc ratios, thinner central corneas, family history of glaucoma, diabetes, myopia, history of migraine headaches, and lower ocular perfusion pressure. ${ }^{19,20}$

\section{Current medical treatments for glaucoma}

Topical ocular hypertensive medications which lower IOP have been the mainstay for first-line treatment of OHT and OAG to even before large, population-based clinical studies identified IOP as a modifiable risk factor. The Ocular Hypertension Treatment Study evaluated 1,636 individuals with an IOP of 24-32 mmHg in one eye and 21-32 mmHg in the fellow eye who were randomized to observation or to topical ocular hypotensive medication. ${ }^{21}$ Early treatment of OHT to lower IOP decreased the cumulative incidence of OAG at a median follow up of 13 years (16\% versus $22 \%$ overall; $\mathrm{p}=0.009$ ).

The Early Manifest Glaucoma Trial was a randomized clinical trial that included 255 patients aged 50-80 years (median, 68 years) with early glaucoma, visual field defects (median mean deviation, $-4 \mathrm{~dB}$ ), and a median IOP of 
$20 \mathrm{mmHg} .{ }^{11}$ These signs were mainly identified through a population screening. The patients were randomized to no initial treatment or to treatment. The treated patients had laser trabeculoplasty and started receiving topical betaxolol twice daily in eligible eyes. Follow-up visits included tonometry and computerized perimetry every 3 months and fundus photography every 6 months. The results suggest that a reduction of $1 \mathrm{mmHg}$ could be correlated with an approximate 10\% decrease in risk for glaucoma progression over a $4-6$ year period. ${ }^{11,12}$ There are five major classes of topical medications currently approved for the treatment of elevated IOP designed to either reduce the production of ocular fluid or facilitate its outflow (Table 1). ${ }^{22-24}$ Until the pathophysiology of glaucoma is better understood, there is little likelihood other therapeutic targets will become a more central component of glaucoma management. Each of these classes of drugs has its own advantages and drawbacks (Table 1). The $\alpha 2$-adrenergic receptor agonists, for instance, decrease the production of aqueous by the ciliary body and act on uveoscleral outflow, but can cause fatigue, high blood pressure or anxiety. While the $\beta$-blockers reduce $\mathrm{AH}$ secretion to lower IOP, and although rarely cause ocular side effects, may cause respiratory and cardiac side effects. ${ }^{22,23}$ Also, unlike the cholinergics, $\beta$-blockers do not affect pupil size. As miotics, the cholinergic agents target the conventional outflow pathway indirectly, by inducing ciliary muscle contraction that expands the TM and dilates Schlemm's canal, reducing outflow resistance; however, they are not used widely due to local side effects. ${ }^{25}$

The side-effect profile of the PGA class of drugs is substantially superior to that of the $\beta$-blockers, which meant that the class quickly became the first-line treatment of choice for many clinicians. This class of drugs is known to cause conjunctival hyperemia, ${ }^{26}$ but the effects are typically considered mild and transient. Other effects include permanent iris color change and periorbital pigmentation and eye lash growth. ${ }^{27}$ PGAs bind primarily to prostaglandin receptors in the TM, ciliary muscle, and sclera, leading to altered matrix metalloproteinases expression..$^{1728}$ The mechanism of action of this class enhances uveoscleral outflow to lower IOP. The first PGA to be approved was latanoprost, and since then other PGAs, including travoprost, tafluprost, bimatoprost, and unoprostone, have also received regulatory approval. ${ }^{29}$

\section{New and emerging glaucoma treatments}

Several new IOP-lowering treatments that target various other mechanisms of action are in late-phase development. Among them is netarsudil (RhopressaTM, AR-13324 [Aerie Pharmaceuticals, Inc, Irvine, CA, US]) ophthalmic solution, which is a small-molecule inhibitor of both Rho-kinase (ROCK) and the norepinephrine transporter (NET). Netarsudil is thought to target the trabecular network and thus the abnormal tissues responsible for elevated IOP in glaucoma. The safety and efficacy of netarsudil monotherapy are being compared with timolol maleate $(0.5 \%)$ in patients with OAG or OHT in two phase III trials (NCT02246764 and NCT02207621, $n=240$ and 690 , respectively). A phase II clinical trial $(n=298)$ showed that in patients with OAG or OHT, a fixed combination of netarsudil $0.02 \%$ and latanoprost (0.005\%) (Roclatan ${ }^{\circledast}$, PG324 [Aerie Pharmaceuticals, Inc, Irvine, CA, US]) showed significantly improved reduction in IOP than either of the two treatments alone $(p<0.0001){ }^{30}$ The most frequently reported adverse event was conjunctival hyperemia, which occurred with an incidence of $41 \%$ (30/73), 40\% (29/73) and 40\% (31/78) in the PG324 0.01\% and PG324 $0.02 \%$ and AR-13324 $0.02 \%$ groups, respectively compared with only $14 \%$ (10/73) in the latanoprost group.
Another class of potential IOP-lowering agents is the adenosine agonists. These bind to adenosine A1 receptors which, in the eye, reduce outflow resistance consequently lowering IOP. ${ }^{31}$ An example is trabodenoson (INO8875), which showed significantly greater reductions in IOP compared with placebo at 14 and 28 days ( $p=0.01$ and $p<0.001$, respectively) in a phase ॥ trial of patients with primary open-angle glaucoma (POAG) or OHT. . $^{32,33}$ The effect on IOP and safety parameters of trabodenoson at three different dose levels (4.5\% twice daily [BID], 6.0\% once daily [QD], 3.0\% QD), timolol $0.5 \% \mathrm{BID}$, and placebo is being compared in a phase III trial in patients (planned $n=335$ ) with POAG and/or OHT (NCT02565173).

A3 adenosine receptor (A3AR) agonists have been found to protect normal cells from undergoing apoptosis via the downregulation of death signals and may be able to prevent RGC apoptosis. ${ }^{31}$ A phase II study on an oral A3AR medication, CF-101, is currently recruiting subjects with OHT and glaucoma (NCT 01033422).

Another class of potential IOP-lowering agents is the selective prostaglandin EP2 receptor agonists. ${ }^{34}$ One member of this class, taprenepag isopropyl (PF-04217329) ${ }^{35,36}$ has been evaluated in a phase II clinical trial $(n=250) .^{37}$ Taprenepag $0.0025-0.03 \%$ dosed daily produced significantly greater reductions in IOP than placebo (vehicle) and showed similar reductions in IOP compared with latanoprost $0.005 \%$ after 14 days in patients with $\mathrm{OHT}$ and OAG. In addition, the combination of taprenepag and latanoprost showed significantly greater reductions in IOP than latanoprost 0.005\% alone.

\section{Latanoprostene bunod-a novel nitric oxide- donating prostaglandin $\mathrm{F}_{2 \alpha}$ analog}

LBN ophthalmic solution $0.024 \%$ is an IOP lowering eye drop dosed once daily in the evening for patients with OAG or OHT and is currently under regulatory review by the FDA. ${ }^{38} \mathrm{LBN}$ is a single entity NO-donating prostaglandin $F_{2 a}$ analog. Following topical ocular administration, LBN is rapidly metabolized by esterases into latanoprost acid and butanediol mononitrate (BDMN), an NO-donating moiety (Figure 1). ${ }^{39}$ BDMN is further metabolized to 1,4-butanediol and the signaling molecule, NO. These two active metabolites each have IOP-lowering properties. This factor and various experimental findings have led to the hypothesis that LBN functions via a dual mechanism of action: by increasing both non-conventional (uveoscleral) $\mathrm{AH}$ outflow via latanoprost acid and conventional (TM/Schlemm's canal) $\mathrm{AH}$ outflow via NO donation (Figure 2). ${ }^{28,40}$

The mechanism of IOP reduction by one of the metabolites, latanoprost acid, the active moiety of latanoprost, has been studied extensively. Latanoprost acid lowers IOP by remodeling the extracellular matrix in the ciliary muscle, which increases the uveoscleral AH outflow. ${ }^{41-45,46}$ Widespread clinical use of the topical PGA latanoprost, an isopropyl ester analog of $\mathrm{PGF}_{2 \alpha^{\prime}}$ is based on its ability to lower IOP to a greater extent than other topical agents with a once daily dosing regimen coupled with minimal side effects. ${ }^{28,47-51}$ The recent United Kingdom Glaucoma Treatment Study was the first randomized, placebocontrolled trial conducted in patients with OAG $(n=516)$ that assessed vision preservation via IOP-lowering in patients treated with latanoprost compared with placebo. ${ }^{52}$ At 24 months, the mean (standard deviation [SD]) IOP reduction from baseline was greater in the latanoprost group (3.8 [4.0] $\mathrm{mmHg}$ ) compared with the placebo group $(0.9$ [3.8] $\mathrm{mmHg}$ ). In 
Figure 1: Metabolism of latanoprostene bunod to two active moieties-latanoprost acid and nitric oxide

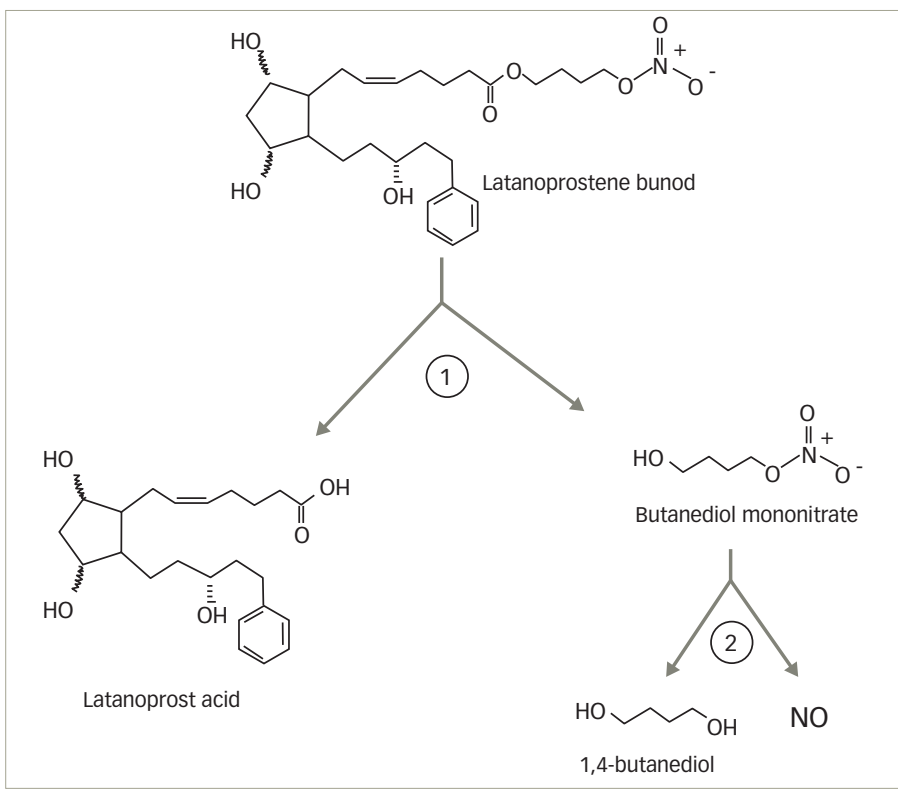

NO $=$ nitric oxide. Reproduced with permission from Kawase $K$ et al. ${ }^{90}$

addition, time-to-first visual field deterioration was significantly longer in the latanoprost group versus placebo group (adjusted hazard risk [HR] $0.44,95 \%$ confidence interval [Cl] 0.28-0.69; $p=0.0003$ ).

The other LBN active metabolite, NO, is a critical physiologic signaling molecule known for its role as a mediator of smooth muscle relaxation and vasodilation in the body. ${ }^{53-55} \mathrm{NO}$ is produced endogenously from L-arginine by NO synthases and signals via the second messenger cyclic guanosine monophosphate (CGMP). ${ }^{40}$ In the healthy eye, NO is produced in anterior ocular tissues, including the TM. ${ }^{56,57}$ Ocular blood flow impairment is hypothesized to contribute to RGC damage ${ }^{58}$ and several studies have suggested a vasodilatory role of NO on ocular blood vessels, ${ }^{59-61}$ although no data are currently available to support the potential for RGC rescue or protective properties for LBN. Endogenous NO has been shown to regulate physiological IOP.62 Decreased NO synthase activity in the TM, Schlemm's canal and ciliary muscle; coupled with decreased NO metabolites levels in the $\mathrm{AH}$ of patients with $\mathrm{OAG}$, suggest that reduced NO production likely contributes to the IOP increase. ${ }^{63-65}$

Outside ophthalmology, nitrovasodilators are used in the treatment and prevention of angina pectoris. In the eye, NO-donating nitrovasodilators have been demonstrated to lower IOP primarily by increasing TM/Schlemm's canal (conventional) outflow. ${ }^{66}$ An early clinical study demonstrated that systemic administration of nitroglycerin resulted in IOP lowering in patients with POAG. ${ }^{67}$ Since then, animal studies have confirmed these nitrovasodilators lower IOP and further demonstrated that this is through an increase in conventional $\mathrm{AH}$ outflow.62,68-71 Numerous in vitro and ex vivo studies also suggest that NO-donors relax the tissues of the conventional outflow pathway ${ }^{57,72-75}$ Ex vivo preparations of bovine and porcine origin also demonstrated the ability of NO donors to reduce AH formation. ${ }^{76,77}$

Alterations in cell contractility/shape could be the basis of NO-donor mediated IOP-lowering. In vitro studies showed that NO donors
Figure 2: Intraocular pressure homeostasis and the dual activity of latanoprostene bunod

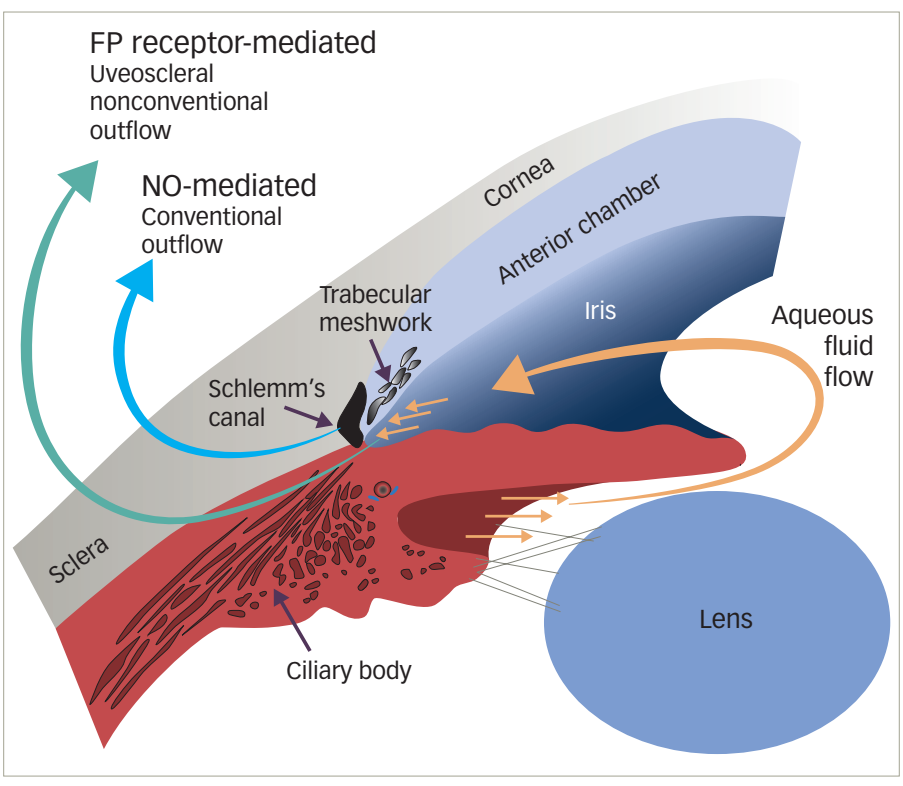

FP $=$ prostaglandin F receptor; $N O=$ nitric oxide

decrease TM cell volume through CGMP signaling and activation of the large-conductance $\mathrm{Ca}^{2+}$-activated $\mathrm{K}^{+}\left(\mathrm{BK}_{\mathrm{Ca}}\right)$ channel. ${ }^{57}$ In addition, NO-donors may induce alterations in the cytoskeletal (actin and myosin) organization of TM and Schlemm's canal cells via an increase in CGMP. ${ }^{57,73,78,79} \mathrm{NO}$ donors have an inhibitory effect on ROCK, downstream of CGMP in the NO soluble guanylate cyclase (SGC)/CGMP pathway. ${ }^{80,81}$ ROCK is a serine-threonine kinase that regulates the shape and movement of cells by acting on the cytoskeleton. ${ }^{82}$ In vascular smooth muscle cells (VSMCS), ROCK mediates the phosphorylation of myosin light chains enabling the contraction of actin fibers. ${ }^{83} \mathrm{TM}$ cells are highly contractile and in this respect, are similar to VSMCs in which NO/SGC/ cGMP signaling activates protein kinase G. Protein kinase $\mathrm{G}$, in turn, promotes relaxation via multiple pathways, including inhibition of ROCK and activation of the large-conductance $\mathrm{Ca}^{2+}$-activated $\mathrm{K}^{+}\left(\mathrm{BK}_{\mathrm{Ca}}\right)$ channel. Activation of the SGC/cGMP signaling pathway may therefore result in relaxation in TM cells and Schlemm's canal, leading to increased aqueous outflow.

Preclinical studies have also demonstrated that LBN has a greater effect on TM cell relaxation than the prostaglandin latanoprost. ${ }^{84}$ Studies in FP-receptor knockout mice and rabbits, a species which does not respond to latanoprost, have demonstrated that while LBN reduces IOP in these models, there is a lack of effective IOP reduction in response to latanoprost treatment, highlighting the contribution of NO to the IOP Iowering efficacy of LBN. ${ }^{39,85}$ LBN also produced greater IOP lowering than latanoprost in animal models of glaucoma or $\mathrm{OHT}^{39}$ In ocularly hypertensive primates, LBN achieved a maximum decrease in IOP of $31 \%$ and $35 \%$ relative to baseline at doses of $0.036 \%(9 \mu g)$ and $0.12 \%$ (36 $\mu g)$, respectively, whereas latanoprost elicited a greater response than vehicle only at $0.1 \%$ $(30 \mu g)$, with a peak effect of $26 \%$. Furthermore, in glaucomatous dogs, IOP decreased from baseline by $44 \%$ and $10 \%$ following LBN $0.036 \%$ and vehicle, respectively, while latanoprost (0.030\%) lowered IOP by $27 \%$ and vehicle by $9 \%{ }^{39}$ 
Table 2: Summary of studies key investigating latanoprostene bunod $0.024 \%$ for the lowering of intraocular pressure

\begin{tabular}{|c|c|c|c|c|c|c|c|}
\hline Study & Phase & $\begin{array}{l}\text { No. of } \\
\text { subjects/ } \\
\text { patients (ITT/ } \\
\text { enrolled) }\end{array}$ & $\begin{array}{l}\text { Patient } \\
\text { group }\end{array}$ & $\begin{array}{l}\text { Baseline IOP, } \\
\text { Mean (SD) mmHg }\end{array}$ & $\begin{array}{l}\text { IOP at follow up or IOP } \\
\text { reduction from baseline }\end{array}$ & Main findings & Reference \\
\hline VOYAGER & ॥ & $413 \mathrm{ITT}$ & $\begin{array}{l}\text { OAG or } \\
\text { OHT }\end{array}$ & $\begin{array}{l}26.01(1.67) \\
\text { (diurnal) }\end{array}$ & $-9.00 \mathrm{mmHg}$ & $\begin{array}{l}\text { Significantly greater IOP lowering and } \\
\text { comparable side effects versus latanoprost } \\
0.005 \%\end{array}$ & $\begin{array}{l}\text { Weinreb et al. } \\
(2015)^{38}\end{array}$ \\
\hline APOLLO & III & $417 \mathrm{ITT}$ & $\begin{array}{l}\text { OAG or } \\
\text { OHT }\end{array}$ & 26.7 (2.5) (diurnal) & $\begin{array}{l}\text { Range, }-7.7 \text { to }-9.1 \mathrm{mmHg} \\
\text { over } 3 \text { months }\end{array}$ & $\begin{array}{l}\text { Significantly greater IOP lowering than timolol } \\
0.5 \% \text { BID throughout the day over } 3 \text { months of } \\
\text { treatment }\end{array}$ & $\begin{array}{l}\text { Weinreb et al. } \\
(2016)^{86}\end{array}$ \\
\hline LUNAR & III & $414 \mathrm{ITT}$ & $\begin{array}{l}\text { OAG or } \\
\text { OHT }\end{array}$ & 26.6 (2.39) (diurnal) & $\begin{array}{l}\text { Range, }-7.5 \text { to }-8.8 \mathrm{mmHg} \\
\text { over } 3 \text { months }\end{array}$ & $\begin{array}{l}\text { LBN } 0.024 \% \text { QD in the evening was noninferior } \\
\text { to timolol 0.5\% BID over } 3 \text { months of } \\
\text { treatment, with significantly greater IOP } \\
\text { lowering in subjects with OAG or OHT at all but } \\
\text { the earliest time point evaluated }\end{array}$ & $\begin{array}{l}\text { Medeiros et al. } \\
(2016)^{87}\end{array}$ \\
\hline JUPITER & III & 130 enrolled & $\begin{array}{l}\text { OAG or } \\
\text { OHT }\end{array}$ & $19.6(2.9)$ & $\begin{array}{l}22.0 \% \text { reduction in IOP } \\
\text { to } 15.3 \text { (3.0) } \mathrm{mmHg} \text { was } \\
\text { achieved by week 4, and } \\
\text { reductions greater than } 22 \% \\
\text { were observed at every } \\
\text { subsequent visit }\end{array}$ & $\begin{array}{l}\text { 1-year treatment with LBN } 0.024 \% \text { provided } \\
\text { significant and sustained IOP reduction }\end{array}$ & $\begin{array}{l}\text { Kawase et al. } \\
(2016)^{90}\end{array}$ \\
\hline CONSTELLATION & ॥ & 25 enrolled & $\begin{array}{l}\text { OHT or } \\
\text { OAG }\end{array}$ & $\begin{array}{l}21.6(2.8) \\
\text { (daytime) } \\
25.7(3.8) \\
\text { (nighttime) }\end{array}$ & $\begin{array}{l}17.6 \text { (2.5) mmHg (daytime) } \\
23.2 \text { (3.4) mmHg (nighttime) }\end{array}$ & $\begin{array}{l}\text { LBN } 0.024 \% \text { reduced IOP over } 24 \text { hours while } \\
\text { timolol only reduced IOP during the daytime. } \\
\text { LBN also improved ocular perfusion pressure } \\
\text { versus baseline during the daytime and versus } \\
\text { timolol during the nocturnal period }\end{array}$ & $\begin{array}{l}\text { Liu et al. } \\
(2016)^{89}\end{array}$ \\
\hline KRONUS & 1 & 24 enrolled & $\begin{array}{l}\text { Healthy } \\
\text { subjects }\end{array}$ & $\begin{array}{l}13.6(1.3)(24 h \\
\text { IOP) }\end{array}$ & $-3.6 \mathrm{mmHg}$ & $\begin{array}{l}\text { Significantly lowered mean IOP in healthy } \\
\text { Japanese subjects over 24-h }\end{array}$ & $\begin{array}{l}\text { Araie et al. } \\
(2015)^{91}\end{array}$ \\
\hline
\end{tabular}

$B I D=$ twice daily; $I O P=$ intraocular pressure; $I T T=$ intent-to-treat; $L B N=$ latanoprostene bunod; $O A G=$ open angle glaucoma; $O H T=$ ocular hypertension; $Q D=$ once daily; $S D=$ standard deviation

\section{Clinical studies investigating the use of latanoprostene bunod in glaucoma}

Clinical studies have defined further the activity of LBN in patients with OAG and OHT (Table 2). The VOYAGER study was a phase II, parallel group, dose-ranging study that compared the efficacy and safety of four different concentrations of LBN with latanoprost $(0.005 \%)$ in patients with OAG or $\mathrm{OHT}^{38}$ Patients were eligible if they had an IOP of $22-32 \mathrm{mmHg}$, and an IOP of $\geq 24 \mathrm{mmHg}$ for at least two of three measurements during visit 3 (Day 1, baseline), which occurred after a 28-day washout period in subjects previously treated with IOP-lowering medications. Patients were randomized to LBN $0.006 \%(n=82)$, LBN 0.012\% ( $n=85)$, LBN 0.024\% ( $n=83)$, LBN $0.040 \%(n=81)$, or latanoprost $0.005 \%(n=82)$ dosed once daily in the evening for 28 days. All doses resulted in significant reductions in mean diurnal IOP from baseline at all follow-up visits $(p<0.0001)$. The response was dose-dependent and plateaued with the $0.024 \%-0.040 \%$ doses LBN $0.024 \%$ was the most effective dose, achieving a greater diurnal IOP reduction compared with latanoprost $0.005 \%$ at Day $28(p=0.005)$. The difference in reduction of diurnal IOP between LBN $0.024 \%$ and latanoprost $0.005 \%$ at Day 28 was $1.23 \mathrm{mmHg}$. On secondary efficacy assessments, there were significantly greater reductions in mean diurnal IOP versus latanoprost at day 7 for the LBN $0.024 \%$ and $0.040 \%$ groups ( $p=0.033$ and 0.009 , respectively), and at Day 14 for the LBN $0.024 \%$ group $(p=0.015)$. Significantly greater reductions in mean IOP were also observed for LBN $0.024 \%$ compared with latanoprost $0.005 \%$ at most individual time points. In addition, a significantly greater proportion of subjects had mean diurnal IOP $\leq 18 \mathrm{mmHg}$ in the LBN $0.024 \%$ group at day 28 compared with the latanoprost $0.005 \%$ group (Figure 3). LBN was well tolerated but instillation site pain appeared to occur more frequently with LBN 0.024\% (12\%) versus latanoprost 0.005\% (6.1\%).

The clinical development program of LBN has continued with two recent phase III, randomized, double-masked, parallel-group clinical studies (APOLLO and LUNAR). The APOLLO study $(n=420)$ was a randomized, controlled, multi-center, double-masked, parallel-group clinical study that compared the 3-month efficacy (IOP reduction) and safety of LBN $0.024 \%$ with that of timolol maleate $0.5 \%$ (randomized 2:1, respectively) in patients with OAG or OHT in one or both eyes (IOP range: $22-36 \mathrm{mmHg}$ ). ${ }^{86}$ Eligible patients had an IOP $\geq 26 \mathrm{mmHg}$ at a minimum of 1 time point, $\geq 24 \mathrm{mmHg}$ at a minimum of one time-point, and $\geq 22 \mathrm{mmHg}$ at one time-point in the same eye, and IOP $\leq 36 \mathrm{mmHg}$ at all three time-points in both eyes at baseline. Eligible patients received topical doses of LBN $0.024 \%$ QD (evening) or timolol 0.5\% BID (morning and evening) for 3 months and IOP measurements were made at baseline (at $8 \mathrm{am}, 12 \mathrm{pm}$ and $4 \mathrm{pm}$ ), and at 8 am, 12 pm and 4 pm during study visits at 2 weeks, 6 weeks and 3 months (nine time points) after the start of treatment.

Mean IOP in the study eye in the intent-to-treat population, which was the primary endpoint, was significantly lower in the LBN 0.024\% group (range, 17.8-18.7 $\mathrm{mmHg}$ ) than the timolol 0.5\% group (range,19.1-19.8 $\mathrm{mmHg}$ ) at all 9 time points ( $p \leq 0.002$ for all), confirming not only non-inferiority to timolol 
Figure 3: Proportions of patients with mean intraocular pressure $\leq 18 \mathrm{mmHg}$ at follow-up visits (intent-to-treat population) in the VOYAGER study

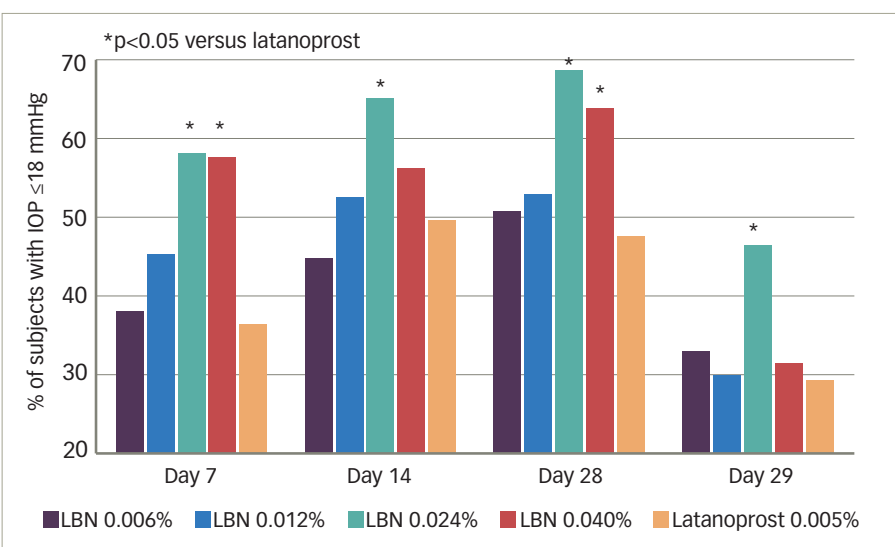

${ }^{*} p<0.05$ versus latanoprost. $1 O P=$ intraocular pressure; $L B N=$ latanoprostene bunod Reproduced with permission from Weinreb et al. 2015. ${ }^{38}$

but significantly greater IOP-lowering to timolol. ${ }^{86}$ The change in mean IOP from baseline was also significantly greater for LBN $0.024 \%$ compared with timolol $0.05 \%$ at all 9 time points ( $\mathrm{p} \leq 0.002$ for all) (Figure 4 ).

For secondary endpoints, at all nine time points, the proportion of subjects with mean IOP $\leq 18 \mathrm{mmHg}$ was significantly greater with LBN $0.024 \%$ versus timolol $0.5 \%$ (mean IOP $\leq 18 \mathrm{mmHg}$ : $22.9 \%$ versus $11.3 \%, \mathrm{p}=0.005$ ). ${ }^{86}$ The percentage of subjects with IOP change from baseline $\geq 25 \%$ was also significantly greater for LBN $0.024 \%$ than timolol $0.05 \%$ (34.9\% versus $19.5 \%, p<0.001)$. A further ANCOVA analysis showed that the mean change from baseline in IOP for LBN $0.024 \%$ (range, -7.7 to $-9.1 \mathrm{mmHg}$ ) was significantly greater than that of timolol $0.5 \%$ (range, -6.6 to -8.0 ) for all nine time points $(p \leq 0.002) .86$

The occurrence and types of ocular adverse events in the APOLLO study were similar in both treatment groups (Table 3). ${ }^{86}$ Treatment-emergent adverse events (TEAES) occurred in $13.4 \%$ of LBN $0.024 \%$ and $11.9 \%$ of timolol $0.5 \%$-treated patients. The most frequent events were eye irritation, conjunctival hyperemia, and eye pain. Two patients in the LBN $0.024 \%$ group and five in the timolol 0.5\% group discontinued due to ocular adverse events. Similar proportions of patients receiving LBN $0.024 \%$ or timolol $0.5 \%$ had non-ocular TEAES (12.7\% and $14.1 \%$, respectively). The proportions of patients with these TEAEs that were considered treatment-related were $1.8 \%$ and $2.2 \%$, respectively. It was concluded that LBN $0.024 \%$ was safe and significantly more effective than timolol $0.5 \%$ for IOP lowering. In addition, the ability to reduce IOP $\leq 18 \mathrm{mmHg}$ with LBN may be a significant advantage over topical $\beta$-blockers.

The findings of the similarly designed LUNAR study $(n=420)$ indicate comparable IOP lowering to the APOLLO study between LBN $0.024 \%$ and timolol $0.5 \%$ over 3 months. ${ }^{87}$ At all but one of the measured time-points (i.e. $12 \mathrm{pm}, 4 \mathrm{pm}$, at week 2, $8 \mathrm{am}, 12 \mathrm{pm}$ and $4 \mathrm{pm}$ at week 6 and month 3), the mean IOP in the study eye was significantly lower in the LBN $0.024 \%$ group than in the timolol $0.5 \%$ group. Results from APOLLO and LUNAR showed that LBN $0.024 \%$ reduced mean IOP values by 7.5 to $9.1 \mathrm{mmHg}$ over the three months' treatment. Following completion of the double-masked efficacy phase, all patients were switched to open-label treatment with
Figure 3: Change from baseline in mean intraocular pressure $(\mathrm{mmHg})$ in the study eye, by visit, time point and treatment group in the APOLLO study comparing latanoprostene bunod (0.024\%) with timolol (0.5\%)

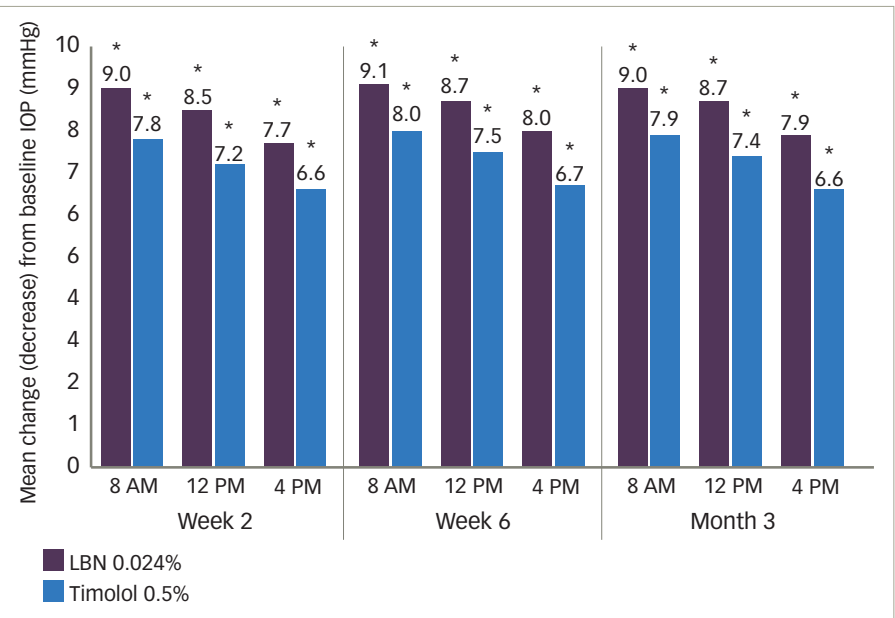

The plotted results are for the intent-to-treat population with last observation carried forward. Mean was the least squares mean of the mean IOP change. APOLLO = Comparing safety and efficacy of latanoprostene bunod $0.024 \%$ with timolol maleate $0.5 \%$ in subjects with open-angle glaucoma or ocular hypertension; $\angle B N=$ latanoprostene bunod. ${ }^{*} p<0.002$ versus timolol at the same assessment point Reproduced with permission from Weinreb et al. $2016 .^{86}$

Table 3: Ocular safety of latanoprostene bunod (0.024\%) versus timolol $(0.5 \%)$ in the treatment of open angle glaucoma or ocular hypertension glaucoma in the APOLLO study

\begin{tabular}{|l|l|l|}
\hline & $\begin{array}{l}\text { LBN }(0.024 \%) \\
\text { study eye } \\
\mathrm{n}=283(\%)\end{array}$ & $\begin{array}{l}\text { Timolol (0.5\%) } \\
\text { study eye } \\
\mathrm{n}=135(\%)\end{array}$ \\
\hline$\geq 1$ ocular TEAE & $38(13.4)$ & $16(11.9)$ \\
\hline$\geq 1$ treatment-related ocular TEAE & $31(11.0)$ & $12(8.9)$ \\
\hline Eye irritation & $11(3.9)$ & $3(2.2)$ \\
\hline Conjunctival hyperemia & $8(2.8)$ & $2(1.5)$ \\
\hline Eye pain & $4(1.4)$ & $3(2.2)$ \\
\hline Dry eye & $3(1.1)$ & $1(0.7)$ \\
\hline Foreign body sensation in eyes & $3(1.1)$ & $0(0.0)$ \\
\hline Instillation site pain & $3(1.1)$ & $2(1.5)$ \\
\hline
\end{tabular}

$A P O L L O=$ Comparing safety and efficacy of latanoprostene bunod with timolol maleate in subjects with open-angle glaucoma or ocular hypertension. LBN = latanoprostene bunod; TEAE = treatment-emergent adverse event. Reproduced with permission from Weinreb et al 2016.86

LBN $0.024 \%$ once daily in the evening for another 9 (APOLLO) or 3 (LUNAR) months. From pooled data from the APOLLO and LUNAR open-label safety extension phase (number of patients completed the studies=737), subjects randomized to timolol who were switched to LBN in the safety extension phase demonstrated an additional 6.3-8.3\% decrease in mean diurnal IOP; IOP lowering was sustained over the entire duration of the studies. ${ }^{88}$ Overall, $18.7 \%$ of subjects who received LBN experienced ocular TEAES (study eye); the most common of these were conjunctival hyperemia (5.9\%), eye irritation (4.6\%), eye pain (3.5\%). The majority (>99.5\%) of ocular TEAEs were mild-moderate in severity. There were no safety issues with regard to ocular signs, best corrected visual acuity (BCVA), and vital signs, or endothelial cell stress with LBN based on specular microscopy. 
Treatment with LBN $0.024 \%$ once daily resulted in IOP lowering during both the diurnal/wake and the nocturnal/sleep period in the CONSTELLATION study. ${ }^{89}$ In this prospective, open-label randomized crossover trial in 25 patients with $\mathrm{OHT}$ or OAG, LBN $0.024 \%$ treatment was associated with a reduction in both diurnal and nocturnal IOP versus baseline whereas timolol $0.5 \%$ reduced IOP only during the diurnal period. ${ }^{89}$ In addition, LBN $0.024 \%$ treatment resulted in a significant increased diurnal ocular perfusion pressure versus baseline and nocturnal ocular perfusion pressure versus timolol $0.05 \%$.

In the single-arm, multicenter, open-label JUPITER study, the long-term safety and efficacy of LBN 0.024\% was studied over 1 year in 130 Japanese subjects with OAG and OHT with a mean (SD) baseline IOP of 19.6 (2.9) $\mathrm{mmHg} .{ }^{90}$ At 52 weeks, the mean reduction in IOP was $5.3 \mathrm{mmHg}$ or greater than $25 \%$ from baseline in the study eye. Long-term treatment in this study provided significant IOP reduction that was sustained up to a year. Finally, LBN $0.024 \%$ dosed QD for 14 days, was showed to significantly lower mean IOP during a 24-hr period in 24 healthy Japanese subjects in the singlecenter, open-label KRONUS study ${ }^{91}$ with a mean (SD) 24-hour reduction of 3.6 (0.8) $\mathrm{mmHg}$ or $27 \%$ from the baseline in the study eye..$^{91}$ Mean (SD) baseline IOP was 13.6 (1.3) mmHg in the study eye..$^{91}$ Peak and trough IOP lowering occurred at $8 \mathrm{AM}$ and $8 \mathrm{PM}$ (i.e. 12 and 24 hours following instillation) with a mean reduction of $4.2(1.8) \mathrm{mmHg}$, or $30 \%$, and $2.8(2.2) \mathrm{mmHg}$, or $20 \%$, respectively.

Collectively, the VOYAGER, APOLLO, LUNAR, CONSTELLATION, JUPITER, and KRONUS study findings are likely to make a robust case for the use of topical LBN $0.024 \%$ in OAG and OHT. Further, data from the JUPITER and KRONUS studies suggest that LBN may by effective in lowering IOP in patients with NTG.

\section{Summary and concluding remarks}

While effective, many of the current topical medical treatments are limited by systemic or local side effects, multiple instillations per day, and lack of 24-hour control of IOP. LBN is hypothesized to increase AH outflow by targeting both the uveoscleral (via latanoprost acid) and TM (via NO) pathways and is under regulatory review by the US FDA as a once-daily single-agent topical medication for IOP lowering in patients with OAG or $\mathrm{OHT}$. Evidence from phase II and phase III clinical studies demonstrated that once-daily LBN lowers IOP in patients with OAG or OHT to a greater extent than latanoprost $0.005 \%$ and timolol $0.5 \% .^{38,87,86}$ The observed $1.23 \mathrm{mmHg}$ difference in mean diurnal IOP change from baseline between LBN $0.024 \%$ and latanoprost $0.005 \%$ in the phase II trial was statistically significant and may be considered clinically significant in reducing the risk for progression of glaucoma. These findings are supported and greatly extended by the results of the larger phase III APOLLO study in which IOP was significantly lower with LBN $0.024 \%$ treatment than timolol $0.5 \%$ at all time points over 3 months. Results from the second phase III (LUNAR) study are consistent with these findings. LBN appears to have a dual mechanism of action in lowering IOP and has demonstrated the potential to provide sustained 24-hour IOP reduction in healthy subjects and patients with elevated IOP.89,91 Obtaining superior effects from fewer doses of medication could make a difference in both patient adherence and compliance. Long-term (1 year) data on LBN's sustained IOP lowering efficacy has recently been published ${ }^{90}$ and further investigation is required to explore the additional beneficial properties and safety with long-term use of LBN and specifically in subjects with NTG.

The addition of LBN QD single-molecule monotherapy that targets both outflow pathways to the glaucoma treatment armamentarium offers the potential of increased IOP lowering efficacy without sacrificing safety when compared with currently available topical glaucoma therapies. $\square$

APOLLO = Latanoprostene Bunod $0.024 \%$ versus Timolol Maleate $0.5 \%$ in Subjects with Open-Angle Glaucoma or Ocular Hypertension: The APOLLO Study

CONSTELLATION = Efficacy of Latanoprostene Bunod Compared with Timolol $0.5 \%$ in Lowering IOP over $24 \mathrm{~h}$

JUPITER = Long-term Safety and Efficacy of Latanoprostene Bunod 0.024\% in Japanese Subjects with Open-Angle Glaucoma or Ocular Hypertension: The JUPITER Study

KRONUS = Evaluation of the Effect of Latanoprostene Bunod Ophthalmic Solution, $0.024 \%$ in Lowering Intraocular Pressure over $24 \mathrm{~h}$ in Healthy Japanese Subjects LUNAR = Comparison of Latanoprostene Bunod $0.024 \%$ and Timolol Maleate $0.5 \%$ in Open-Angle Glaucoma or Ocular Hypertension: LUNAR

VOYAGER = A Randomised, Controlled Comparison of Latanoprostene Bunod and Latanoprost $0.005 \%$ in the Treatment of Ocular Hypertension and Open Angle Glaucoma: the VOYAGER Study

1. Kingman S, Glaucoma is second leading cause of blindness globally, Bull World Health Organ, 2004;82:887-8.

2. Pascale A, Drago F, Govoni S, Protecting the retinal neurons from glaucoma: lowering ocular pressure is not enough, Pharmacol Res, 2012;66:19-32

3. Vidal-Sanz M, Salinas-Navarro M, Nadal-Nicolas FM, et al., Understanding glaucomatous damage: anatomical and functional data from ocular hypertensive rodent retinas, Prog Retin Eye Res, 2012;31:1-27.

4. Weinreb RN, Khaw PT, Primary open-angle glaucoma, Lancet, 2004;363:1711-20.

5. Weinreb RN, Aung T, Medeiros FA, The pathophysiology and treatment of glaucoma: a review, JAMA, 2014:311:1901-11.

6. Vajaranant TS, Wu S, Torres M, Varma R, The changing face of primary open-angle glaucoma in the United States: demographic and geographic changes from 2011 to 2050, Am J Ophthalmol 2012;154:303-14.e3

7. Tham YC, Li X, Wong TY, Quigley HA, et al., Global prevalence of glaucoma and projections of glaucoma burden through 2040: a systematic review and meta-analysis, Ophthalmology 2014:121:2081-90.

8. Bengtsson B, Leske MC, Hyman L, Heijl A, Early Manifest Glaucoma Trial G. Fluctuation of intraocular pressure and glaucoma progression in the early manifest glaucoma trial, Ophthalmology, 2007;114:205-9.

9. Quigley HA, Broman AT, The number of people with glaucoma worldwide in 2010 and 2020, Br J Ophthalmol, 2006:90:262-7.

10. Mi XS, Yuan TF, So KF, The current research status of normal tension glaucoma, Clin Interv Aging, 2014:9:1563-71.
11. Heiil A, Leske MC, Bengtsson B, et al., Reduction of intraocular pressure and glaucoma progression: results from the Early Manifest Glaucoma Trial, Arch Ophthalmol, 2002;120:1268-79.

12. Leske MC, Heijl A, Hussein M, et al., Factors for glaucoma progression and the effect of treatment: the early manifest glaucoma trial, Arch Ophthalmol, 2003:121:48-56.

13. Kass MA, Heuer DK, Higginbotham EJ, et al., The Ocular Hypertension Treatment Study: a randomized trial determines that topical ocular hypotensive medication delays or prevents the onset of primary open-angle glaucoma, Arch Ophthalmol, 2002;120:701-13; discussion 829-30.

14. Agarwal R, Gupta SK, Agarwal P, et al., Current concepts in the pathophysiology of glaucoma, Indian J Ophthalmol, 2009:57:257-66.

15. Fautsch MP, Johnson DH, Aqueous humor outflow: what do we know? Where will it lead us?, Invest Ophthalmol Vis Sci, 2006;47:4181-7.

16. Goel M, Picciani RG, Lee RK, Bhattacharya SK, Aqueous humor dynamics: a review, Open Ophthalmol J, 2010;4:52-9.

17. Winkler NS, Fautsch MP, Effects of prostaglandin analogues on aqueous humor outflow pathways, J Ocul Pharmacol Ther, 2014:30:102-9.

18. Johnstone $M A$, Intraocular pressure regulation: findings of pulse-dependent trabecular meshwork motion lead to unifying concepts of intraocular pressure homeostasis, J Ocul Pharmaco Ther, 2014;30:88-93.

19. Coleman AL, Miglior S, Risk factors for glaucoma onset and progression, Surv Ophthalmol, 2008:53 Suppl1:S3-10.

20. Furlanetto RL, De Moraes $C G$, Teng CC, et al., Risk factors for optic disc hemorrhage in the low-pressure glaucoma treatment study Am J Ophthalmol, 2014;157:945-52.

21. Kass MA, Gordon MO, Gao F, et al., Delaying treatment of ocula hypertension: the ocular hypertension treatment study, Arch Ophthalmol, 2010;128:276-87.

22. Bettin P, Di Matteo F, Glaucoma: present challenges and future trends, Ophthalmic Res, 2013:50:197-208.

23. Wentz SM, Kim NJ, Wang J, et al., Novel therapies for open-angle glaucoma, F1000Prime Rep, 2014;6:102.

24. Kolko M, Present and New Treatment Strategies in the Management of Glaucoma, Open Ophthalmol J, 2015;9:89-100

25. Toris CB, Pharmacotherapies for glaucoma, Curr Mol Med, 2010:10:824-40.

26. Aptel $F$, Cucherat $M$, Denis P, Efficacy and tolerability of prostaglandin analogs: a meta-analysis of randomized controlled clinical trials, J Glaucoma, 2008;17:667-73.

27. Rao RC, Ballard TN, Chen TC, Iris heterochromia and unilateral eyelash hypertrichosis, JAMA, 2015;313:1967-8.

28. Toris $\mathrm{CB}$, Gabelt $\mathrm{BT}$, Kaufman $\mathrm{PL}$, Update on the mechanism of action of topical prostaglandins for intraocular pressure reduction, Surv Ophthalmol, 2008:53 Suppl1:S107-20

29. Lee AJ, McCluskey P, Clinical utility and differential effects of prostaglandin analogs in the management of raised intraocular pressure and ocular hypertension, Clin Ophthalmol, 2010;4:741-64.

30. Lewis RA, Levy B, Ramirez N, et al., Fixed-dose combination of AR-13324 and latanoprost: a double-masked, 28-day, randomised, controlled study in patients with open-angle glaucoma or ocular hypertension, Br J Ophthalmol, 2015;100:339-44. 
31. Zhong $Y$, Yang $Z$, Huang WC, Luo X, Adenosine, adenosine receptors and glaucoma: an updated overview, Biochim Biophys Acta, 2013:1830:2882-90.

32. Myers J, Sall K, DuBiner $\mathrm{H}$, et al., A randomized, phase II study of trabodenoson (INO-8875) in adults with ocular hypertension (OHT) or primary open-angle glaucoma (POAG), Invest Ophthalmol Vis SCi, 2013:54:2261.

33. Myers JS, Sall KN, DuBiner $\mathrm{H}$, et al., A dose-escalation study to evaluate the safety, tolerability, pharmacokinetics, and efficacy of 2 and 4 weeks of twice-daily ocular trabodenoson in adults with ocular hypertension or primary open-angle glaucoma, J Ocul Pharmacol Ther. 2016.

34. Ganesh T, Prostanoid receptor EP2 as a therapeutic target, J Med Chem, 2014:57:4454-65.

35. Prasanna G, Carreiro S, Anderson S, et al., Effect of PF-04217329 a prodrug of a selective prostaglandin EP(2) agonist on intraocular pressure in preclinical models of glaucoma, Exp Eye Res, 2011;93:256-64.

36. Yanochko GM, Affolter T, Eighmy JJ, et al., Investigation of ocular events associated with taprenepag isopropyl, a topical EP2 agonist in development for treatment of glaucoma, $J$ OCu Pharmacol Ther 2014:30:429-39.

37. Schachar RA, Raber S, Courtney R, Zhang M. A phase 2, randomized, dose-response trial of taprenepag isopropyl (PF04217329) versus latanoprost $0.005 \%$ in open-angle glaucom and ocular hypertension, Curr Eye Res, 2011;36:809-17.

38. Weinreb RN, Ong T, Scassellati Sforzolini B, et al., A randomised, controlled comparison of latanoprostene bunod and latanoprost $0.005 \%$ in the treatment of Ocular hypertension and open angle glaucoma: the VOYAGER study, Br I Ophthalmol, 2015:99:738-45

39. Krauss AH, Impagnatiello F, Toris CB, et al., Ocular hypotensive activity of BOL-303259-X, a nitric oxide donating prostaglandi F2alpha agonist, in preclinical models, Exp Eye Res, 2011;93:250-5

40. Cavet ME, Vittitow JL, Impagnatiello F, et al., Nitric oxide (NO): an emerging target for the treatment of glaucoma, Invest Ophthalmol Vis Sci, 2014:55:5005-15

41. Lindsey JD, Kashiwagi K, Kashiwagi F, Weinreb RN, Prostaglandins alter extracellular matrix adjacent to human ciliary muscle cells in vitro, Invest Ophthalmol Vis Sci, 1997;38:2214-23.

42. Richter M, Krauss AH, Woodward DF, Lutjen-Drecoll E, Morphological changes in the anterior eye segment after longterm treatment with different receptor selective prostaglandin agonists and a prostamide, Invest Ophthalmol Vis SCi 2003:44:4419-26.

43. Gabelt BT, Kaufman PL, Prostaglandin F2 alpha increases uveoscleral outflow in the cynomolgus monkey, Exp Eye Res, 1989:49:389-402.

44. Lutjen-Drecoll E, Tamm E, Morphological study of the anterior segment of cynomolgus monkey eyes following treatment with prostaglandin F2 alpha, Exp Eye Res, 1988;47:761-9.

45. Nilsson SF, Samuelsson M, Bill A, Stjernschantz J, Increased uveoscleral outflow as a possible mechanism of ocular hypotension caused by prostaglandin F2 alpha-1-isopropylester in the cynomolgus monkey, Exp Eye Res, 1989:48:707-16.

46. Gaton DD, Sagara T, Lindsey JD, et al., Increased matrix metalloproteinases 1, 2, and 3 in the monkey uveoscleral outflow pathway after topical prostaglandin F(2 alpha)-isopropyl ester treatment, Arch Ophthalmol, 2001;119:1165-70

47. Digiuni M, Fogagnolo P, Rossetti L, A review of the use of latanoprost for glaucoma since its launch, Expert Opin Pharmacother, 2012:13:723-45.

48. Alm A, Camras CB, Watson PG, Phase III latanoprost studies in Scandinavia, the United Kingdom and the United States, Surv Ophthalmol, 1997;41 Suppl 2:S105-10.

49. Goldberg I, Li XY, Selaru P, Paggiarino D, A 5-year, randomized, open-label safety study of latanoprost and usual care in patients with open-angle glaucoma or ocular hypertension, Eur $J$ Ophthalmol, 2008;18:408-16.

50. Rouland JF, Traverso CE, Stalmans I, et al., Efficacy and safety of preservative-free latanoprost eyedrops, compared with BAKpreserved latanoprost in patients with ocular hypertension or glaucoma, Br J Ophthalmol, 2013;97:196-200.

51. Allaire $\mathrm{C}$, Dietrich $\mathrm{A}$, Allmeier $\mathrm{H}$, et al., Latanoprost $0.005 \%$ test formulation is as effective as Xalatan(R) in patients with ocular hypertension and primary open-angle glaucoma, Eur 」 Ophthalmol, 2012:22:19-27.

52. Garway-Heath DF, Crabb DP, Bunce C, et al., Latanoprost for openangle glaucoma (UKGTS): a randomised, multicentre, placebocontrolled trial, Lancet, 2015;385:1295-304.

53. Becquet $F$, Courtois $Y$, Goureau O, Nitric oxide in the eye: multifaceted roles and diverse outcomes, Surv Ophthalmol, 1997:42:71-82.

54. Palmer RM, Ferrige AG, Moncada S, Nitric oxide release accounts for the biological activity of endothelium-derived relaxing factor, Nature, 1987:327:524-6.

55. Goldstein IM, Ostwald P, Roth $S$, Nitric oxide: a review of its role in retinal function and disease, Vision Res, 1996;36:2979-94.

56. Haufschild T, Tschudi MR, Flammer J, et al., Nitric oxide production by isolated human and porcine ciliary processes, Graefes Arch Clin Exp Ophthalmol, 2000;238:448-53.

57. Schneemann A, Dijkstra BG, van den Berg TJ, et al., Nitric oxide/ guanylate cyclase pathways and flow in anterior segment perfusion, Graefes Arch Clin Exp Ophthalmol, 2002:240:936-41.

58. Flammer J, Orgul S, Optic nerve blood-flow abnormalities in glaucoma, Prog Retin Eye Res, 1998;17:267-89.

59. Benedito S, Prieto D, Nielsen PJ, Nyborg NC, Role of the endothelium in acetylcholine-induced relaxation and spontaneous tone of bovine isolated retinal small arteries, Exp Eye Res, 1991:52:575-9.

60. Delaey C, Van de Voorde J, The effect of NO donors on bovine retinal small arteries and posterior ciliary arteries, Invest Ophthalmol Vis Sci, 1998:39:1642-6.

61. Okamura T, Kitamura Y, Uchiyama M, et al., Canine retinal arterial and arteriolar dilatation induced by nipradilol, a possible glaucoma therapeutic, Pharmacology, 1996;53:302-10.

62. Chang JY, Stamer WD, Bertrand J, et al., Role of nitric oxide in murine conventional outflow physiology, Am J Physiol Cell Physio , 2015;309:C205-14.

63. Doganay S, Evereklioglu C, Turkoz Y, Er H, Decreased nitric oxide production in primary open-angle glaucoma, Eur $J$ Ophthalmol 2002:12:44-8

64. Galassi F, Renieri G, Sodi A, et al., Nitric oxide proxies and ocular perfusion pressure in primary open angle glaucoma, $\mathrm{Br}$ J Ophthalmol, 2004;88:757-60.

65. Nathanson JA, McKee M, Alterations of ocular nitric oxide synthase in human glaucoma, Invest Ophthalmol Vis SCi. 1995:36:1774-84.

66. Nathanson JA. Nitrovasodilators as a new class of ocular hypotensive agents. J Pharmacol Exp Ther, 1992;260(3):956-65.

67. Wizemann A, Wizemann V, [The use of organic nitrates to lower intraocular pressure in outpatient and surgical treatmen (author's transl)]. Article in German, Klin Monbl Augenheilkd 1980;177:292-5.

68. Schuman JS, Erickson K, Nathanson JA, Nitrovasodilator effects on intraocular pressure and outflow facility in monkeys, Exp Eye Res, 1994:58:99-105.

69. Lei $Y$, Zhang $X$, Song $M$, et al., Aqueous humor outflow physiology in NOS3 knockout mice, Invest Ophthalmol Vis Sci, 2015;56:4891-8

70. Kotikoski H, Vapaatalo H, Oksala O, Nitric oxide and cyclic GMP enhance aqueous humor outflow facility in rabbits, Curr Eye Res, 2003:26:119-23

71. Heyne GW, Kiland JA, Kaufman PL, Gabelt BT. Effect of nitric oxide on anterior segment physiology in monkeys. Invest Ophthalmol Vis Sci. 2013:54(7):5103-10.

72. Dismuke WM, Liang J, Overby DR, Stamer WD, Concentrationrelated effects of nitric oxide and endothelin-1 on human trabecular meshwork cell contractility, Exp Eye Res, 2013;120C:28-35

73. Dismuke WM, Mbadugha CC, Ellis DZ, NO-induced regulation of human trabecular meshwork cell volume and aqueous humor outflow facility involve the BKCa ion channel, Am J Physiol Cell Physiol, 2008:294:C1378-86.
74. Ellis DZ, Dismuke WM, Chokshi BM, Characterization of soluble guanylate cyclase in $\mathrm{NO}$-induced increases in aqueous humor outflow facility and in the trabecular meshwork, Invest ophthalmol Vis Sci, 2009;50:1808-13.

75. Ellis DZ, Sharif NA, Dismuke WM, Endogenous regulation of human Schlemm's canal cell volume by nitric oxide signaling, Invest Ophthalmol Vis Sci, 2010:51:5817-24.

76. Millar JC, Shahidullah M, Wilson WS, Intraocular pressure and vascular effects of sodium azide in bovine perfused eye, $\mathrm{J} \mathrm{OCul}$ Pharmacol Ther, 2001:17:225-34.

77. Shahidullah M, Yap M, To CH, Cyclic GMP, sodium nitroprusside and sodium azide reduce aqueous humour formation in the isolated arterially perfused pig eye, Br J Pharmacol, 2005;145:84-

78. Kaufman PL, Rasmussen CA, Advances in glaucoma treatment and management: outflow drugs, Invest Ophthalmol Vis Sci, 2012:53:2495-500

79. Kotikoski H, Alajuuma P, Moilanen E, et al., Comparison of nitric oxide donors in lowering intraocular pressure in rabbits: role of cyclic GMP, J Ocul Pharmacol Ther, 2002;18:11-23.

80. Buys ES, Potter $L R$, Pasquale $L R$, Ksander BR, Regulation of intraocular pressure by soluble and membrane guanylate cyclases and their role in glaucoma, Front Mol Neurosci, 2014;7:38

81. Thoonen R, Sips PY, Bloch KD, Buys ES, Pathophysiology of hypertension in the absence of nitric oxide/cyclic GMP signaling, Curr Hypertens Rep, 2013;15:47-58.

82. Wang SK, Chang RT, An emerging treatment option for glaucoma: Rho kinase inhibitors, Clin Ophthalmol, 2014:8:883-90.

83. Arnal JF, Dinh-Xuan AT, Pueyo M, et al., Endothelium-derived nitric oxide and vascular physiology and pathology, Cell Mol Life SCi, 1999;55:1078-87.

84. Cavet ME, Vollmer TR, Harrington $\mathrm{KL}$, et al., Regulation of endothelin-1-induced trabecular meshwork cell contractility by latanoprostene bunod, Invest Ophthalmol Vis SCi, 2015:56:4108-16.

85. Saeki T, Tsuruga $\mathrm{H}$, Aihara M, et al., Dose-Response Profile of PF-03187207 (PF-207) and Peak IOP Lowering Response Following Single Topical Administration to FP Receptor Knockout Mice vs. Wild Type Mice, Invest Ophthalmol Vis Sci, 2009;50:4064.

86. Weinreb RN, Sforzolini Sforzolini B, Vittitow J, Liebmann J. Latanoprostene bunod $0.024 \%$ versus timolol maleate $0.5 \%$ in subjects with open-angle glaucoma or ocular hypertension, Ophthalmology, 2016;123:965-73.

87. Medeiros FA, Martin KR, Peace $\rfloor$, et al, Comparison of latanoprostene bunod $0.024 \%$ and timolol maleate $0.5 \%$ in openangle glaucoma or ocular hypertension: The LUNAR study, Am J Ophthalmol, 2016:168:250-9.

88. Vittitow JL, Liebmann JM, Kaufman PL, et al., Long-term efficacy and safety of latanoprostene bunod $0.024 \%$ for intraocula pressure lowering in patients with open-angle glaucoma or ocular hypertension: APOLLO and LUNAR studies, Invest Ophthalmol Vis SCi, 2016;57:3030.

89. Liu JH, Slight JR, Vittitow JL, et al., Efficacy of latanoprostene bunod $0.024 \%$ compared with timolol $0.5 \%$ in lowering intraocular pressure over 24 hours, Am J Ophthalmol, 2016:169:249-57.

90. Kawase K, Vittitow JL, Weinreb RN, Araie M, Long-term safety and efficacy of latanoprostene bunod $0.024 \%$ in Japanese subjects with open-angle glaucoma or ocular hypertension: The JUPITER study, Adv Ther, 2016:33:1612-27.

91. Araie M, Sforzolini BS, Vittitow J, Weinreb RN, Evaluation of the effect of latanoprostene bunod ophthalmic solution, $0.024 \%$ in lowering intraocular pressure over $24 \mathrm{~h}$ in healthy Japanese subjects, Adv Ther, 2015;32:1128-39. 